\title{
Prevalence of surgical site infection post caesarean with increased patient load during COVID-19 pandemic in tertiary care centre
}

\author{
Prashansa Raut*, Reena Wani, Theertha Shetty, Roshni Khade, Anjali Mulchandani
}

Department of Obstetrics and Gynecology, Dr. R. N. Cooper Hospital and HBT Medical College, Juhu, Mumbai, Maharashtra, India

Received: 26 May 2021

Revised: 04 July 2021

Accepted: 04 July 2021

*Correspondence:

Dr. Prashansa Raut,

E-mail: prashansa.raut@gmail.com

Copyright: () the author(s), publisher and licensee Medip Academy. This is an open-access article distributed under the terms of the Creative Commons Attribution Non-Commercial License, which permits unrestricted non-commercial use, distribution, and reproduction in any medium, provided the original work is properly cited.

\section{ABSTRACT}

Background: Increased referrals and workload during the pandemic lead to overcrowding in hospitals and increase in LSCS rates. Surgical site infection is one of the most common complication post LSCS causing physical and mental duress to the patients. The objective of the study was to analyse the effect of COVID-19 on SSI, the incidence, commonly associated factors and bacteriology of SSI. The design was prospective study design.

Methods: 577 patients undergoing LSCS were studied from Day 1 till 30 days post LSCS from $1^{\text {st }}$ August 2020 to $31^{\text {st }}$ October 2020.

Results: Out of 577, 28 (4.85\%) patients developed SSI. 60\% of SSI in our study were unbooked, 50\% had haemoglobin less than $9.9 \mathrm{~g} / \mathrm{dl}$. Most common risk factor for developing of SSI included pre-eclampsia (32.14\%) followed by previous LSCS (28.57\%). Common organism isolate was MRSA (25\%) and 75\% required surgical management.

Conclusions: Regular ANC visits can help in managing comorbidities at an earlier stage leading to reduction in SSI. Strict aseptic precautions should be followed to reduce SSI in cases with PROM and second stage arrest. SSI rate is not influenced by COVID-19 status but hospital facilities and overcrowding definitely have an effect.

Keywords: COVID-19, Caesarean section, Surgical site infection, Tertiary care centre, Pandemic

\section{INTRODUCTION}

Surgical site infection (SSI) is second most common hospital acquired infection. The rate of SSI ranges from $2.5 \%$ to $41.9 \%$ globally. Infections occurring in the wound are major barriers for healing which shows impact on patients, which may prolong the hospital stay and affects the quality of life. ${ }^{2}$

Wound healing requires a healthy environment which will result in normal healing process and also with minimal scar formation. ${ }^{3}$
We at R.N. Cooper Hospital and HBT Medical College are tertiary care centre and referral point for many peripheral hospitals and maternity homes. Since elective surgeries were on hold owing to COVID-19 pandemic, the most commonly performed procedure was lower segment caesarean section (LSCS).

Aim

Primary aim

The aim of the study was to determine incidence of SSI during peak COVID-19 era in tertiary care centre among 
patients undergoing LSCS and to identify risk factors for SSI (patient related, facility related).

\section{Secondary aim}

The aim of the study was to identify common bacterial pathogens causing SSI and to suggest methods to reduce occurrence of SSI based on findings.

\section{METHODS}

The study type was prospective observational study design. The study was carried out Dr. R. N. Cooper Municipal General Hospital and HBT Medical College. The study period was $1^{\text {st }}$ August 2020 to $31^{\text {st }}$ October 2020 .

\section{Selection criteria}

All patients undergoing LSCS over this period were reviewed with respect to demographic wound outcome, risk factors. Total number of confinements in this period were 1220. Patients undergoing caesarean were 577. Caesarean Section rate in this period being $47 \%$

\section{Procedure}

Our study group included 28 women reporting with surgical site infections post caesarean section. Informed consent taken from every patient for the inclusion in study. The beneficial effect of antibiotic prophylaxis in reducing occurrences of infection associated with elective or emergency caesarean section is already well established. ${ }^{4}$ Standard LSCS protocols were followed. In all the patients undergoing LSCS, prophylactic preoperative dose of IV Antibiotics was given atleast half hour prior and continued post operatively for 3 days. Antibiotics were started priory in patients with PROM. All the caesarean were jointly performed by consultant obstetrician and resident. Standard operative protocols for maintaining asepsis were followed. Post-operative check dressing was done on day 4. For every patient reporting with SSI, wound culture and sensitivity was sent in R. N. Cooper hospital microbiology department. For most caesarean cases, operative time was not more than 1 hour. We analysed following parameters in our study group: type of LSCS, whether patient was booked in ANC period or referred at section, maternal age, haemoglobin at the time of caesarean, BMI of patient, risk factors if present any during pregnancy, degree of SSI, type of organisms cultured from the swab sent, if patient had previous caesarean section and how were the SSI managed.

Ethical approval was obtained from the institutional ethics committee.

\section{Statistical analysis}

Data analysis was done using SPSS software (Chi square test).

\section{RESULTS}

Out of total 1220 confinement, we had 577 LSCS (rate $47 \%$ ). In our study, out of 577 caesareans done in the said period, 28 patients $(4.85 \%)$ developed SSI. Out of these we categorised patients based on type of procedure (emergency vs elective), any additional procedure (obstetrics hysterectomy, internal iliac ligation), indication for LSCS, associated risk factors, degree of SSI, wound swab, and management were analysed.

\section{Type of LSCS}

Chi square $=3.82, \quad \mathrm{p}$ value $<0.05$ were statistically significant. High LSCS rate was due to referrals and surprisingly there was no increase SSI seen in emergency group. Among the 28 cases, 24 (85\%) patients developed SSI after emergency caesarean and $4(14 \%)$ after elective LSCS. Total LSCS were 577 (47\%) out of which 555 (97\%) were emergency LSCS (Table 1).

Table 1: Type of LSCS.

\begin{tabular}{|c|c|c|c|}
\hline SSI & Emergency & Elective & Total \\
\hline Yes & 25 & 3 & 28 \\
\hline No & 530 & 19 & 549 \\
\hline Total & 555 & 22 & 577 \\
\hline
\end{tabular}

Note: Chi square $=3.82, \quad \mathrm{p}$ value $<0.05$ were statistically significant.

\section{Booked/unbooked}

Almost $34 \%$ of cases out of 1220 were referred from periphery and other hospitals (Table 2).

Table 2: Booked/unbooked.

\begin{tabular}{|lllll|}
\hline Variables & $\begin{array}{l}\text { Total } \\
\text { confine } \\
\text {-ment }\end{array}$ & $\begin{array}{l}\text { Percent- } \\
\text { age (\%) }\end{array}$ & $\begin{array}{l}\text { SSI (out } \\
\text { of 28) }\end{array}$ & $\begin{array}{l}\text { Percent- } \\
\text { age (\%) }\end{array}$ \\
\hline Booked & 810 & 66.39 & 11 & 39.28 \\
\hline Unbooked & 410 & 33.60 & 17 & 60.71 \\
\hline
\end{tabular}

\section{Maternal age}

Maximum of the SSIs were in the age group of 21-30 years, because maximum pregnancies are in this age group (Table 3).

Table 3: Maternal age.

\begin{tabular}{|lll|}
\hline Maternal age (years) & Number & Percentage $(\%)$ \\
\hline $\mathbf{2 0}$ and $<\mathbf{2 0}$ & 2 & 7.14 \\
\hline $\mathbf{2 1 - 2 5}$ & 11 & 39.28 \\
\hline $\mathbf{2 6 - 3 0}$ & 11 & 39.28 \\
\hline$>\mathbf{3 0}$ & 4 & 14.28 \\
\hline
\end{tabular}




\section{Risk factors}

Among the risk factors for SSI, hypertension in pregnancy had maximum $(32.14 \%$ ) patients (Table 4 ).

Table 4: Risk factors.

\begin{tabular}{|lll|}
\hline Risk factors & Number & Percentage (\%) \\
\hline PIH & 9 & 32.14 \\
\hline GDM & 2 & 7.14 \\
\hline PREV LSCS & 8 & 28.57 \\
\hline PROM & 2 & 7.14 \\
\hline $2^{\text {nd }}$ stage arrest & 3 & 10.71 \\
\hline COVID positive & 2 & 7.14 \\
\hline
\end{tabular}

\section{Haemoglobin}

In our study of 3 months, $14(50 \%)$ of patients had $\mathrm{Hb}$ between 8-9.9 gm/dl (Table 5).

Table 5: Haemoglobin.

\begin{tabular}{|lll|}
\hline Risk factors & Number & Percentage (\%) \\
\hline$<\mathbf{8}$ & 2 & 7.14 \\
\hline $\mathbf{8 - 9 . 9}$ & 14 & 50 \\
\hline$>\mathbf{1 0}$ & 12 & 42.85 \\
\hline
\end{tabular}

\section{History of previous LSCS}

28.5\% patients had SSI in repeat caesarean sections (Table 6)..

Table 6: History of previous LSCS.

\begin{tabular}{|lll|}
\hline History & Number & Percentage (\%) \\
\hline Previous LSCS & 8 & 28.57 \\
\hline No previous surgery & 20 & 71.42 \\
\hline
\end{tabular}

\section{Body mass index (BMI)}

Obesity classification according to $\mathrm{WHO}$ and AsiaPacific guidelines- underweight $<18.5 \mathrm{~kg} / \mathrm{m}^{2}$, ideal $=18.5$ $22.9 \mathrm{~kg} / \mathrm{m}^{2}$, overweight $=23-24.9 \mathrm{~kg} / \mathrm{m}^{2}$, and obese $>25$ $\mathrm{kg} / \mathrm{m}^{2}$ (Table 7).

Table 7: BMI.

\begin{tabular}{|lll|}
\hline BMI $\left(\mathrm{kg} / \mathrm{m}^{\mathbf{2}}\right)$ & Number & Percentage (\%) \\
\hline $\mathbf{1 1 8 . 5}$ & 0 & - \\
\hline $\mathbf{1 8 . 5 - 2 2 . 9}$ & 10 & 35.71 \\
\hline $\mathbf{2 3 - 2 4 . 9}$ & 8 & 28.57 \\
\hline $\mathbf{2 5 - 2 9 . 9}$ & 6 & 21.42 \\
\hline $\boldsymbol{> 3 0}$ & 4 & 14.28 \\
\hline
\end{tabular}

\section{Degree of SSI}

We did not had any organ/space SSI. 26 (92.86\%) cases had superficial SSI (Table 8).
Table 8: Degree of SSI.

\begin{tabular}{|lll|}
\hline Degree of SSI & Number & Percentage (\%) \\
\hline Superficial & 26 & 92.86 \\
\hline Deep & 2 & 7.14 \\
\hline Organ/space & 0 & 0 \\
\hline
\end{tabular}

\section{Organism cultured from wound swab}

We found that $35.71 \%$ cultures were sterile. In our hospital the most commonly isolated organism was MRSA (25\%), followed by gram positive cocci (Table 9).

Table 9: Organism cultured from wound swab.

\begin{tabular}{|lll|}
\hline Type of organism & Number & Percentage (\%) \\
\hline MRSA & 7 & 25 \\
\hline Gram positive & 6 & 21.42 \\
\hline Acinobacter spp & 2 & 7.14 \\
\hline Gram negative & 2 & 7.14 \\
\hline Sterile & 10 & 35.71 \\
\hline Pseudomonas & 1 & 3.57 \\
\hline
\end{tabular}

\section{Management of SSI}

Out of 28 SSI, 21 (75\%) required re-suturing and in other $7(25 \%)$ spontaneous healing occurred after daily aseptic dressing and secondary intension (Table 10).

Table 10: Management of SSI.

\begin{tabular}{|lll|}
\hline Management of SSI & Number & Percentage $(\%)$ \\
\hline Conservative & 7 & 25 \\
\hline Re-suturing & 21 & 75 \\
\hline
\end{tabular}

\section{LSCS of COVID-19 positive patients}

There was no significant difference in SSI among COVID19 positive patients (Table 11).

Table 11: LSCS of COVID positive patients.

\begin{tabular}{|llll|}
\hline Variables & LSCS & SSI & Percentage (\%) \\
\hline COVID positives & 35 & 2 & 5.71 \\
\hline COVID negatives & 542 & 26 & 4.79 \\
\hline
\end{tabular}

\section{DISCUSSION}

SSI is surgical complication which causes physical as well as mental disturbances to patients, especially postpartum. SSI is the second most common infectious complication after urinary tract infection following caesarean delivery. ${ }^{5}$ We had total confinement of 1220 in the said period. 577 patients underwent LSCS. We kept a follow up of all 577 patients. Out of which $28(4.85 \%)$ patients developed SSI. 27 had LSCS only 1 had additional procedure of obstetric hysterectomy in view of PPH. 
$60 \%$ of SSI in our study were unbooked (17 out of 28 ) which correlates with Amenu et al study. ${ }^{6}$ August to October 2020 being the COVID-19 time, our institution had $33.60 \%$ referred cases for confinement out of 1220 . Rate of SSI in booked cases was $1.35 \%$ and in unbooked cases $4.17 \%$. In booked cases antenatal care given to patients improves their nutrition, anaemia and management of comorbidities are taken care at earlier stage.

We had 555 emergency LSCS (4.50\%) during this period and 22 elective LSCS. There was no significant increase in SSI among Emergency cases. Patients with anaemia are more prone to postpartum infections and has been proved by other studies. ${ }^{7}$ Anaemia diminishes resistance to infection and is frequently associated with puerperal sepsis. In our study $50 \%$ had haemoglobin less than 9.9 $\mathrm{g} / \mathrm{dl}$.

Among the risk factors included in study around $32.14 \%$ had hypertensive disorder correlating to incidence seen in Schneid et al study. ${ }^{8}$ On contrary only $7.14 \%$ has gestational diabetes which is known to cause postpartum infections. Association could not be explained because we had only 2 patients with GDM in our study.

We had total 78 confinement of COVID-19 positive patients in this duration, out of which 35 were LSCS. Only 2 patients $(5.71 \%)$ developed SSI, and SSI rate in COVID-19 negative patients was $4.79 \%$. This shows SSI rate is not influenced by COVID status.

$28.5 \%$ of the cases in our study had a repeat CS which correlates with Oslen et al study. ${ }^{9}$

Premature rupture of membranes is associated with largest bacterial inoculum and liquor gets infected. According to study of Devi et al PROM seen in $27 \%$ cases. ${ }^{10}$ But PROM accounted for only $7.14 \%$ of SSI in our study. This could be because of limited time period of study.

$10.71 \%$ patients had LSCS after second stage arrest. Study of Amenu et al has shown that cases of prolonged or obstructed labour are associated with higher incidences of SSI. ${ }^{6}$ As it aids for ascent of microbial pathogens from lower genital tract to upper genital tract. All the second stage arrest patients were referred to our centre from periphery hospitals.

Majority of SSI were superficial $92.86 \%$ and only 2 cases $(7.14 \%)$ were deep including breech in rectus sheath.

BMI of more than 25 has been shown to affect the outcome of surgery. ${ }^{11}$ However in our study, out of 28 patients $75 \%$ were below $\mathrm{BMI}=25$. May be because patients in our hospital are mostly belonging to lower middle class and lower class. $30 \%$ of the cases in our study had a repeat CS which correlates with Olsen et al study. ${ }^{9}$
In our study $35.71 \%$ cultures were sterile (Table 9). Most common organism being MRSA-Methicillin resistant Staphylococcus aureus (25\%) followed by other grampositive cocci $(21.42 \%)$, Acinobacter spp $(7.14 \%)$, gram negative organism (7.14\%). According to operative obstetrics, common causative organisms leading to postLSCS SSI include gram-negative bacteria, anaerobes, and Staphylococcus aureus. ${ }^{12} 75 \%$ patients of SSI that is 21 required re-suturing and were posted for same after starting appropriate antibiotics according to culture sensitivity report, till report arrives daily dressing was continued. Other $25 \%$ patients had spontaneous healing after daily aseptic dressing and care of wound.

Our study had a few limitations as, small sample size and short study period. This was a single centre study, so the results could not be generalized and applied to all the centres of India. Causative agents of SSI could not be ascertained. Co-relation between causes was not defined. Demographic criteria of the study participants were different which could be a basis of bias.

\section{CONCLUSION}

Surgical Site Infections increased in COVID times with MRSA being commonly identified organism. COVID positive status does not affect SSI rates, but factors like increased referral, lack of regular antenatal visits in lockdown, overcrowding in hospital definitely had contributory effect. Correction of anaemia, control of GDM, adequate nutrition in pregnancy and management of hypertensive disorders in ANC period contribute in avoiding SSI.

Strict aseptic precautions should be followed intrapartum to reduce SSI, especially in cases with PROM and Second stage arrest.

\section{ACKNOWLEDGMENTS}

All the authors thank the Department of obstetrics gynaecology, preventive social medicine and department of microbiology of Dr. R. N. Cooper Hospital for supporting the study.

Funding: No funding sources

Conflict of interest: None declared

Ethical approval: The study was approved by the Institutional Ethics Committee

\section{REFERENCES}

1. Leo A, Piffer S, Ricci F, Manzi A, Poggi E, Porretto V, Fambri P, et al. Surgical site infections in an Italian surgical ward: a prospective study. Surg Infect. 2009;10(6):533-8.

2. Kotz P, Fisher J, Cluskey P, Hartwell SD, Dharma H. Use of a new silver barrier dressing, ALLEVYN Ag in exuding chronic wounds. Int Wound $\mathbf{J}$. 2009;6(3):186-94. 
3. Waili N, Salom K, Ghamdi AA. Honey for wound healing, ulcers, and burns; data supporting its use in clinical practice. Scient World J. 2011;11:766-87.

4. Baaqeel H, Baaqeel R. Timing of administration of prophylactic antibiotics for caesarean section: a systematic review and meta-analysis. BJOG. 2013;120(6):661-9.

5. Hillan EM. Postoperative morbidity following Caesarean delivery. J Adv Nurs. 1995;22(6):1035-42.

6. Amenu D, Belachew T, Araya F. Surgical site infection rate and risk factors among obstetric cases of jimma university specialized hospital, southwest ethiopia. Ethiop J Health Sci. 2011;21(2):91-100.

7. Weber WP, Zwahlen M, Reck S, Misteli H, Rosenthal $\mathrm{R}$, Buser AS, et al. The association of preoperative anemia and perioperative allogeneic blood transfusion with the risk of surgical site infection. Transfusion. 2009;49(9):1964-70.

8. Schneid KN, Sheiner E, Levy A, Holcberg G. Risk factors for post caesarean surgical site infection Obstet Gynaecol. 2000;95(3):367-71.
9. Olsen MA, Butler AM, Willers DM, Devkota P, Gross GA, Fraser VJ. Risk factors for surgical site infection after low transverse cesarean section. Infect Control Hosp Epidemiol. 2008;29(6):477-84.

10. Devi SL, Durge DVK. Surgical site infections post cesarean section. Int $\mathbf{J}$ Reprod Contracept Obstet Gynecol. 2018;7:2486-9.

11. Kofman N, Sheiner E, Levy A, Holcberg G. Risk factors for wound infection following cesarean deliveries. Int J Gynaecol Obstet. 2005;90(1):10-5.

12. Cunningham FG, Dorsten JP. Operative Obstetrics. 2nd ed. New York, NY: McGraw Hill; 2002.

13. Pan WH, Yeh WT. How to define obesity? Evidencebased multiple action points for public awareness, screening, and treatment: an extension of AsianPacific recommendations. Asia Pac J Clin Nutr. 2008;17(3):370-4.

Cite this article as: Raut $\mathrm{P}$, Wani R, Shetty T, Khade R, Mulchandani A. Prevalence of surgical site infection post caesarean with increased patient load during COVID-19 pandemic in tertiary care centre. Int J Reprod Contracept Obstet Gynecol 2021;10:3053-7. 